\title{
THE LEVEL OF CORPORATE SOCIAL RESPONSIBILITY DISCLOSURE OF VIETNAMESE COMMERCIAL BANKS
}

\author{
NGUYEN THI MAI HUONG ${ }^{1}$, TRAN THI THANH HUYEN ${ }^{2}$, NGUYEN THI PHUONG THUY ${ }^{3}$ \\ ${ }^{1}$ Banking University Ho Chi Minh City, ${ }^{2}$ Nguyen Tat Thanh University, ${ }^{3}$ Industrial University Ho Chi \\ Minh City; \\ huongntm@buh.edu.vn,ttthuyen@ntt.edu.vn,nguyenthiphuongthuy@iuh.edu.vn
}

\begin{abstract}
Based on the analysis of Corporate Social Respondsibility (CSR) performance of Vietnamese commercial banks, the paper measures the factors affecting the presentation of CSR in the financial statements, from which proposed solutions to contribute improve the level of CSR announcement. The paper uses qualitative research methods (surveys, interviews) in combination with quantitative research methods (descriptive statistics, model analysis) to determine the level of impact of firm size, return on assets (ROA), financial leverage, board size and board independence to the level of CSR disclosure by Vietnamese commercial banks. The results of the regression model test showed that only the factor of board independence has a positive influence on the announcement of CSR of Vietnamese commercial banks.
\end{abstract}

Keywords. corporate social responsibility, CSR, trading commercial bank.

\section{THEORY OF THE CORPORATE SOCIAL RESPONSIBILITY}

\section{Definition of Corporate Social Responsibility}

The environmental aspect in particular or Corporate Social Responsibility (CSR) of the business is not a new issue, but actually originated in the nineteenth century. The concept of CSR gained recognition in the 1950s, in the book Bowen (1953), mentioned the obligations of entrepreneurs on the political aspect before making action decisions that affect the item social norms and values. In the 1970s, a review was presented by Friedman [11] and stated that the only social responsibility of businesses was to increase profits and maximize value for shareholders. Later, new concepts of CSR began to emerge in the 1980 s, articles on social responses from companies, public policies and especially the theory of stakeholders and business ethics. A notable contribution to strategic management was published by Edward Freeman in 1984 [9], who rejected Friedman's theory [11] and said that the value of an organization's business is not only is in taking care of interests for shareholders but also stakeholders. He laid the foundation for the discussion on the theory of stakeholders and business ethics in the following years. Accordingly, the main issues of concern during this period are business activities, environmental pollution, occupational safety, discrimination and the relationship between CSR and the enterprise's profit. In 2011, Michael Porter and Mark Kramer introduced CSR as a new concept focusing on the connection between social and economic progress [17]. Specifically, shared values are created when corporate policies and activities increase a company's competitiveness, while promoting social and economic conditions in the communities where it operates. They said that the value of sharing is not about personal values as well as values created by the company, but instead is expanding value added related to social and economic aspects such as market value, reputation value and long-term competitive advantage.

Thus, we understand that CSR is an information channel that supports the assessment of consensus between social values, which are covered by the company's activities and social norms; Social conviction that organizations are meeting their social expectations. At the same time to guide the implementation of CSR and publicize specific figures to assess the level of implementation, the legal documents regulating CSR implementation of the organization were born in turn: Guidance of the Organization for Economic Cooperation and Development (OECD) on multinational corporations; ISO 9000 on quality management systems, ISO 14000 on environmental management systems and ISO 26000 on CSR standards; GRI G4 is 
issued by the Global Reporting Initiative to address standards for measuring CSR including economy, environment and society.

\section{Meaning of the presentation of information "social responsibilities" on the financial report}

Traditional financial statements presented on the basis of accounting standards and regimes, but only in the past, so they do not meet the current information needs of users. Today, changes in the international business environment follow the trend of integration, requiring a review of the nature and content of the financial statements of enterprises. Financial statements information not only attaches financial information, but also includes non-financial information. According to previous researchers, when measuring the quality of information, often used quantitative and focused on specific aspects of financial information such as: quality of profit, model of matching value ... Financial statements information is understood in a broader, more multidimensional sense. The different dimensions of the financial statements information are directed towards the usefulness of the information, so it must be based on financial and non-financial information as well as mandatory and voluntary disclosures as reported. Annual financial statements of enterprises. Financial reporting information ensures essential functions for efficient capital markets, so in addition to providing traditional financial statements according to legal regulations, businesses need to supplement the voluntary report on analytical and evaluation of managers' predictions [16].

An emerging trend in business is happening all over the world, companies will show financial and non-financial information in a single integrated report. Companies around the world have begun to realize that their investors are not only focused on financial information but are increasingly interested in compassion and sustainability. This demonstrates the need to report on CSR of business organizations. Currently, the criterion is considered an important measure to improve the competitiveness of businesses on the path of integration and is the driving force to contribute to the growth and prosperity in each country, which is information about CSR.

Each enterprise, when voluntarily deciding on the implementation of its social responsibilities, besides its contributions and costs for the benefit of the social community, of course, has its own business benefits, through its activities, it is:

- According to the survey results of the World Business Council for the Sustainable Development (WBCSD): $80 \%$ of members make sustainable reports according to a separate report, ie the entire source of information on sustainable issues is presented separately, not with any report at all; a few businesses present CSR in sustainability reports in Integrated Reports; and nearly $75 \%$ of sustainability reports are prepared according to GRI guidelines. Thus, presenting and announcing CSR as a condition for enterprises to participate in international economic integration;

- Some studies show that there is a correlation between sustainable development and business performance and profitability of enterprises. Therefore, the lack of information on CSR can lose business cooperation opportunities, attract investment capital from responsible business investors;

- According to research conducted by the marketing firm Environics in 20 countries around the world, the company's social prestige plays a huge role for investors. Through public reporting, transparency, accountability and organizational efforts in specific activities for sustainable development, it helps organizations strengthen the confidence of related parties, increase prestige, brand of business.

\section{Characteristics of "social responsibility" in commercial banks}

Compared to many other industries, a major feature of the banking industry is the extent to which social impacts will depend on the size of users, but the extent of spread will be high and fast to stakeholders. This results in significantly more complex information asymmetry. In terms of stakeholders, 
the main expectations of customers include product safety and providing relevant information. Workers want a safe workplace that is free from discrimination and respect for dignity, while competitors want to compete fairly. Banks not only need to observe the direct environmental impact of their operations, but also the impact of their lending activities. The context of this is the United Nations principles of responsible investment, emphasizing the importance of "comprehensive finance" for vulnerable groups without "producing" products and diversified financial services.

Another characteristic of the banking industry is to ensure systemic stability, so it is characterized by stricter and different regulations; Since then, the practical requirements of CSR are also given certain characteristics. In addition to the general characteristics of CSR in enterprises, there is a particular emphasis on accountability in the areas of bank lending, investment management and asset management, where anti-bribery and money laundering are those particularly important issue is the main factor of anticorruption. This is an important part of banks' CSR activities. Therefore, although banks have little direct impact on the environment, CSR has indirect impacts through providing credit to companies causing environmental pollution, producing unsafe products or human rights violations. Indirect impacts may arise not only in relation to users of banking services, but also suppliers, which is one of the important links affecting responsible supply chain management based on on the basis of integrating environmental and social aspects into supplier policies adopted for finance.

CSR needs to adopt a value-oriented approach to become an integral part of daily operations and incorporated into the organizational culture of business organizations in general and commercial banks in particular. Now, more and more people think that making business decisions must not only consider profit maximization but also voluntarily contribute to solving social problems because it is not economic benefits that are their moral responsibility. In the traditional way of maximizing profit is an important goal of the organization, but in order to survive, develop and compete long-term, bank equity should integrate CSR initiatives into business operations, through Figure 1.

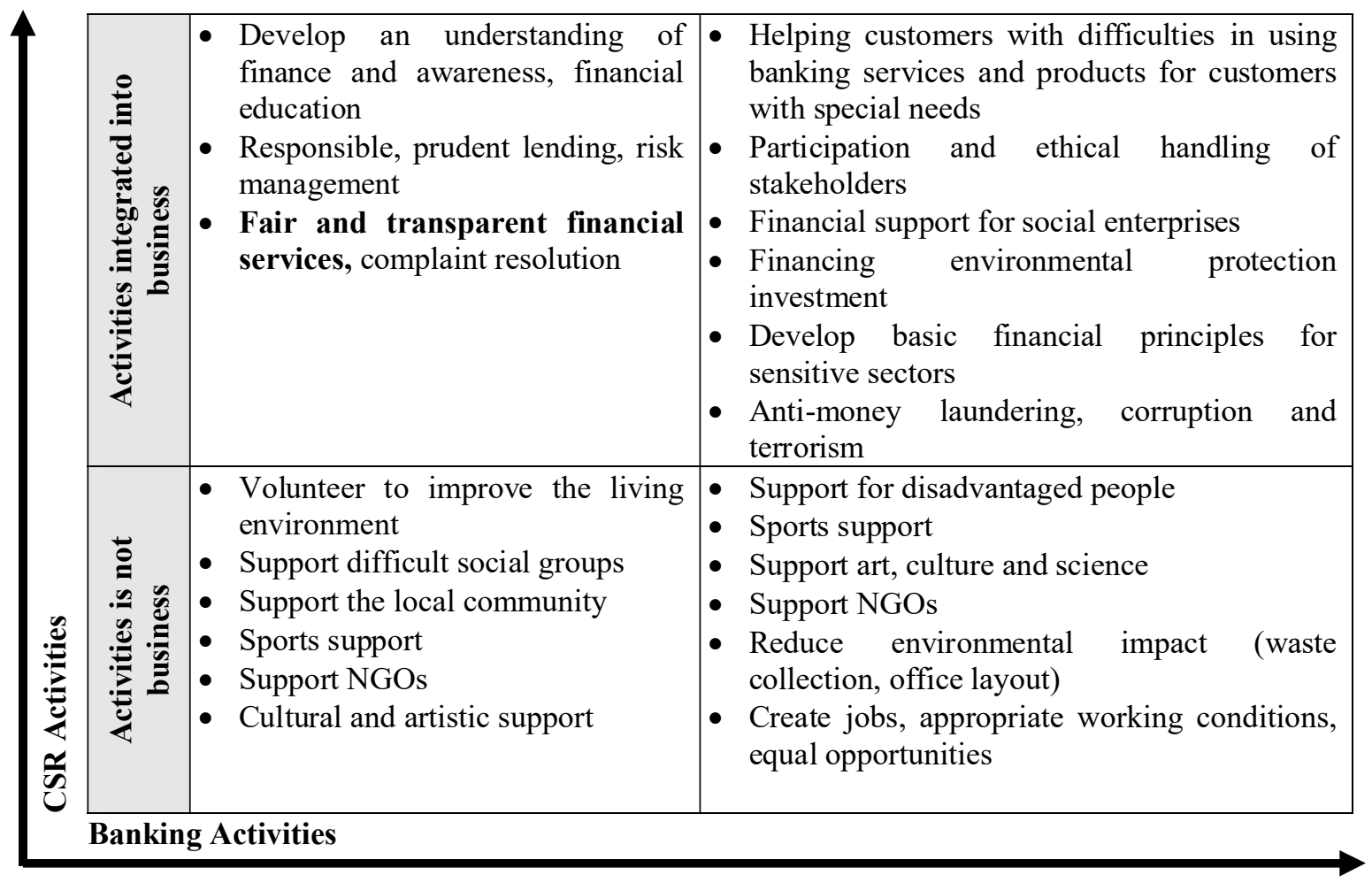

Figure 1. Operation model of CSR in banking organization 


\section{THE LEVEL OF CORPORATE SOCIAL RESPONSIBILITY DISCLOSURE OF VIETNAM COMMERCIAL BANKS}

\section{1 Research design}

\subsubsection{Research process}

Qualitative research: This is a preliminary research step to refine the variables included in the research model, check the scales used, consult the experts' opinions. The author carries out the research by collecting, classifying, compiling and analyzing data in relation to the topic. The aggregated content is the basis for determining research gap.

Quantitative research: Quantitative research was conducted to re-test the scales in the research model. This is a detailed analysis of CSR information collection data presented on the annual report of commercial banks listed on Vietnam stock exchange. After the screening process, 30 banks were selected to be included in the survey sample with the number of banks listed on HNX, HoSE, OTC and UPCoM exchanges respectively $03,07,18$ and 02 .

\section{Research issues}

The level of corporate social responsibility disclosure of Vietnamese commercial banks

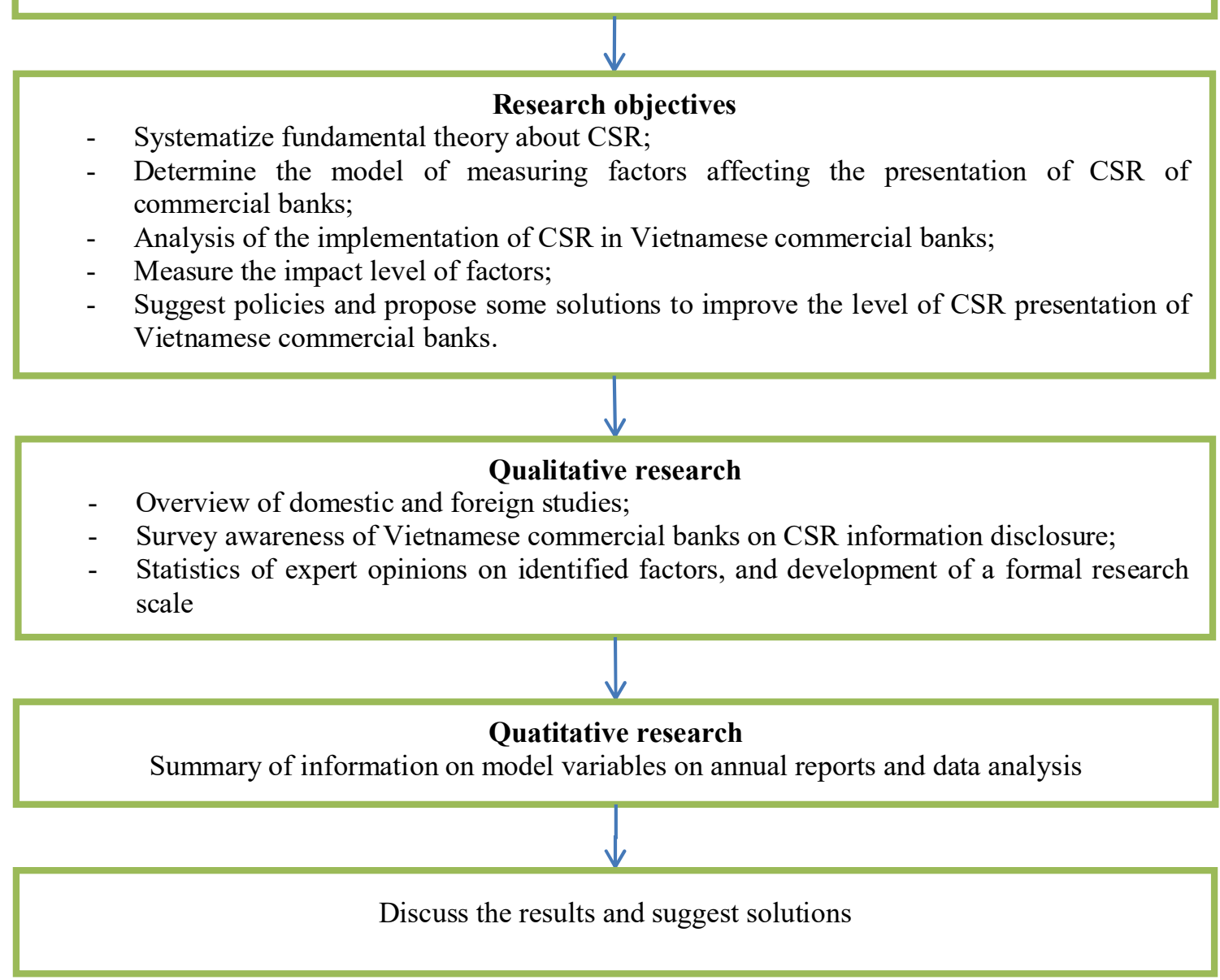

Figure 2. Detailed research process 


\subsubsection{Data collection}

CSR disclosure is gathered from annual reports including the social and environmental activities of more than 30 banks from 2016 to 2018. Following, inheriting the research of Gray et al. [3], we use point assigning techniques to measure CSR disclosure based on the existence criteria and the comprehensiveness of information.

Table 1. Scale measuring CSR disclosure

\begin{tabular}{|l|c|}
\hline \multicolumn{1}{|c|}{ CSR disclosure level } & Score \\
\hline $\begin{array}{l}\text { CSR disclosure presented on financial statements has specific values } \\
\text { and is compared with the previous year }\end{array}$ & 3,0 \\
\hline $\begin{array}{l}\text { CSR disclosure presented on financial statements has specific values but } \\
\text { not comparable to the previous year }\end{array}$ & 2,0 \\
\hline CSR disclosure presented on financial statements & 1,0 \\
\hline There is no information about CSR presented in the financial statements & 0 \\
\hline
\end{tabular}

We examine the content of four CSR indicators: product, environmental and social responsibilities, sustainable workers and jobs and the community [4]. Therefore, a maximum of three points for each indicator and 12 points is the maximum total score for each bank's CSR information disclosure. The CSR information disclosure scale is the actual survey score on the maximum point a bank can achieve.

\subsubsection{Model to study the factors affecting the level of CSR disclosure of Vietnamese commercial banks}

Based on the results of the previous study review, we developed a model to study the impact of factors: board independence, board size, financial leverage, ROA, company size for CSR information disclosure. The scale for each independent variable is shown in detail in Table 2.

Table 2. The scale for independent variables

\begin{tabular}{|l|l|}
\hline \multicolumn{1}{|c|}{ Independent variables } & \multicolumn{1}{c|}{ Scale } \\
\hline Board independence & $\begin{array}{l}\text { Number of independent board } \\
\text { members not operating }\end{array}$ \\
\hline Board size & $\begin{array}{l}\text { Number of members of the board of } \\
\text { directors }\end{array}$ \\
\hline Financial leverage & Rate of after-tax profit on equity \\
\hline ROA & Rate of return on total assets \\
\hline Company size & Total assets \\
\hline
\end{tabular}

We rely on the GRI.G4 standard to develop criteria for measuring the level of CSR disclosure of commercial banks, detailed in Table 3 below.

Table 3. Criteria of CSR information aggregated from GRI.G4 standard

\begin{tabular}{|c|c|l|}
\hline \multirow{4}{*}{ CSR } & $\begin{array}{c}\text { THE POLICIES AT } \\
\text { THE PLACE OF } \\
\text { WORK }\end{array}$ & $\begin{array}{l}\text { The bank encourages employees to develop career skills and opportunities } \\
\text { workplace (eg, distribution of benefits, working regulations, etc.) }\end{array}$ \\
\cline { 3 - 3 } & The bank has policies to protect health, safety and other benefits at work \\
\cline { 3 - 3 } & $\begin{array}{l}\text { The bank has facilitated workers to balance work with private life (eg } \\
\text { flexible working time, leave, etc.) }\end{array}$ \\
\hline MARKET & The bank has a policy of ensuring honesty and fairness in contracts with \\
\hline
\end{tabular}




\begin{tabular}{|c|c|}
\hline \multirow[t]{5}{*}{ POLICIES } & partners \\
\hline & $\begin{array}{l}\text { The bank provides complete and accurate information about products and } \\
\text { ensures after-sales service for buyers }\end{array}$ \\
\hline & The bank commits to pay on time the accounts payable to partners \\
\hline & $\begin{array}{l}\text { The bank has a complaint process, resolves disputes with customers and } \\
\text { other stakeholders }\end{array}$ \\
\hline & The bank co-operates with related parties to resolve joint disputes \\
\hline \multirow{5}{*}{$\begin{array}{l}\text { ENVIRONMENTAL } \\
\text { POLICIES }\end{array}$} & $\begin{array}{l}\text { The bank tries to reduce energy consumption during its operation (eg, } \\
\text { assigning norms of electricity, water, telephone use, etc.) }\end{array}$ \\
\hline & $\begin{array}{l}\text { The bank has tried to minimize and reuse waste during its operation (eg, } \\
\text { photocopied paper, how to use office supplies, etc.) }\end{array}$ \\
\hline & $\begin{array}{l}\text { The bank has made an effort to protect the natural environment - around } \\
\text { the place where it operates }\end{array}$ \\
\hline & $\begin{array}{l}\text { The bank takes into account environmental factors when considering } \\
\text { lending to investment projects }\end{array}$ \\
\hline & $\begin{array}{l}\text { The bank provides environmental information on product brands (eg } \\
\text { information related to employees' rights, community, customers, etc.) }\end{array}$ \\
\hline \multirow{4}{*}{$\begin{array}{l}\text { POLICIES FOR } \\
\text { THE COMMUNITY }\end{array}$} & $\begin{array}{l}\text { The bank often supports and facilitates activities in the locality - where the } \\
\text { organization is conducting business activities }\end{array}$ \\
\hline & $\begin{array}{l}\text { The bank has established close relationships with local authorities to solve } \\
\text { problems arising during the operation }\end{array}$ \\
\hline & $\begin{array}{l}\text { The bank encourages employees to participate in local community } \\
\text { activities }\end{array}$ \\
\hline & $\begin{array}{l}\text { Bank sponsors community activities and projects (health, education, } \\
\text { public transport) }\end{array}$ \\
\hline
\end{tabular}

\subsection{Performance of CSR disclosure of Vietnamese commercial banks}

Based on the results of direct surveys from managers and employees working at commercial banks, we found:

- CSR has existed in the process of implementing activities at the bank; aspects of CSR related to Employees; Customer; Environment and Community are implemented;

- The level of CSR implementation has been implemented quite fully on the criteria, in particular, it is evident in the aspect of CSR assessment related to environmental aspects;

- How to implement unevenly between financial years as well as allocating value among resources. In the research data on the Annual Report we found that most focused on describing the activities of the Community criterion;

- When aggregating commercial banks' data on annual reports, we cannot synthesize the costs for each bank's annual CSR because financial institutions do not uniformly use value measures when announcing criteria; 
- Vietnamese commercial banks do not agree on how to present information about CSR on financial statements: Some criteria are presented in the direction of listing activities (Workplace, Market), besides, some activities identify cost value loss (Community). Therefore, it is very difficult for writers to design a regression model to determine the relationship to measure the cost of implementing CSR with the profit that the unit created in this period. In other words, commercial banks are not interested and aware of the importance of CSR in improving their long-term competitiveness.

Our research results confirm that the CSR index of Vietnamese commercial banks is being implemented to deal with the law, lacks a lot of transparent information, does not guarantee accounting principles when presenting information. With the aggregate information from the actual study of information disclosure of these commercial banks, we conclude that: Vietnamese credit institutions have certain awareness and actions to show their CSR implementation of the unit. However, in order to transform CSR activities to meet the information needs of stakeholders, and become a competitive tool of units, especially in the period of deep integration level today, it is still not satisfactory, or in other words, at a very low level. Therefore, the need to identify factors affecting the implementation and announcement of CSR on the financial statements of commercial banks is very necessary.

\subsection{Measuring factors affecting CSR disclosure of Vietnamese commercial banks}

Analysis results on both Tobit and OLS regression models are very consistent with Gray et al., Ibrahim et al., Lee et al.. From the data used for content analysis, our findings suggest that the board's independence characteristics are significantly related to the disclosure of CSR. In particular, our study shows that the independence of the board has a negative impact on the disclosure of CSR on the financial statements of Vietnamese commercial banks.

Pursuant to Decree 71/2017/ND-CP, the definition of standards and conditions for independent members of the Board of Directors with the Enterprise Law, in particular, independent members of the Board are members specified in Clause 2 Article 151, Enterprise Law: "Independent member of the Board as stipulated in Point b, Clause 1, Article 134 of this Law contains the following criteria and conditions, unless otherwise provided for by the securities law:

a) Not a person working for the company or subsidiary of the company; not the one who worked for the company or subsidiary of the company for at least the previous 3 years;

b) Not being a person who is receiving salary or remuneration from the company, except for allowances that the Board members are entitled to according to regulations;

c) Not a person with a spouse, biological father, adoptive father, natural mother, adoptive mother, biological child, adopted child, biological brother or sister, or younger brother who is a major shareholder of the company; is the manager of the company or its subsidiary;

d) Not a person who directly or indirectly owns at least $1 \%$ of the total voting shares of the company;

e) Not the person who used to be a member of the Board of Directors, Supervisory Board of the company for at least the previous 5 years.

The criteria and conditions for this independence can be classified into two main categories: independence in personal relations (points a, c, e) and independence in relations of ownership and economy (points b, d).

In addition, Circular 95/2017/TT-BTC guides some articles of Decree 71/2017/ ND-CP guiding corporate governance applicable to public companies that the Ministry of Finance has just issued. and effective from November 6, 2017. For listed companies, the total number of independent members of the Board of Directors must account for at least $1 / 3$ of the total members of the Board. For unlisted public companies, the total number of non-executive members of the Board of Directors must account for at least $1 / 3$ of the total members of the Board. If unlisted public companies operate according to the model prescribed at Point b, Clause 1, Article 134 of the Enterprise Law, the structure of the Board of Directors of the company must ensure that at least $1 / 5$ of the total number of members of the Board is independent 
member. In case the number of members of the Board of Directors of the company is less than 5, the company must ensure that there is one member of the Board of Directors who is an independent member. The low independence of the board is an inevitable consequence of long-term state ownership. However, data collected from Vietnam's 30 listed commercial banks only have 3/30 commercial banks (STB (3/9), SGB (2/3), VIETCAPITALBANK (2/5)) achieving the criteria by quantity of independent member of the Board. This explains why there is the opposite effect of the independent variable $\mathrm{X} 2$ on the dependent variable Y.

Table 4. Tobit regression results

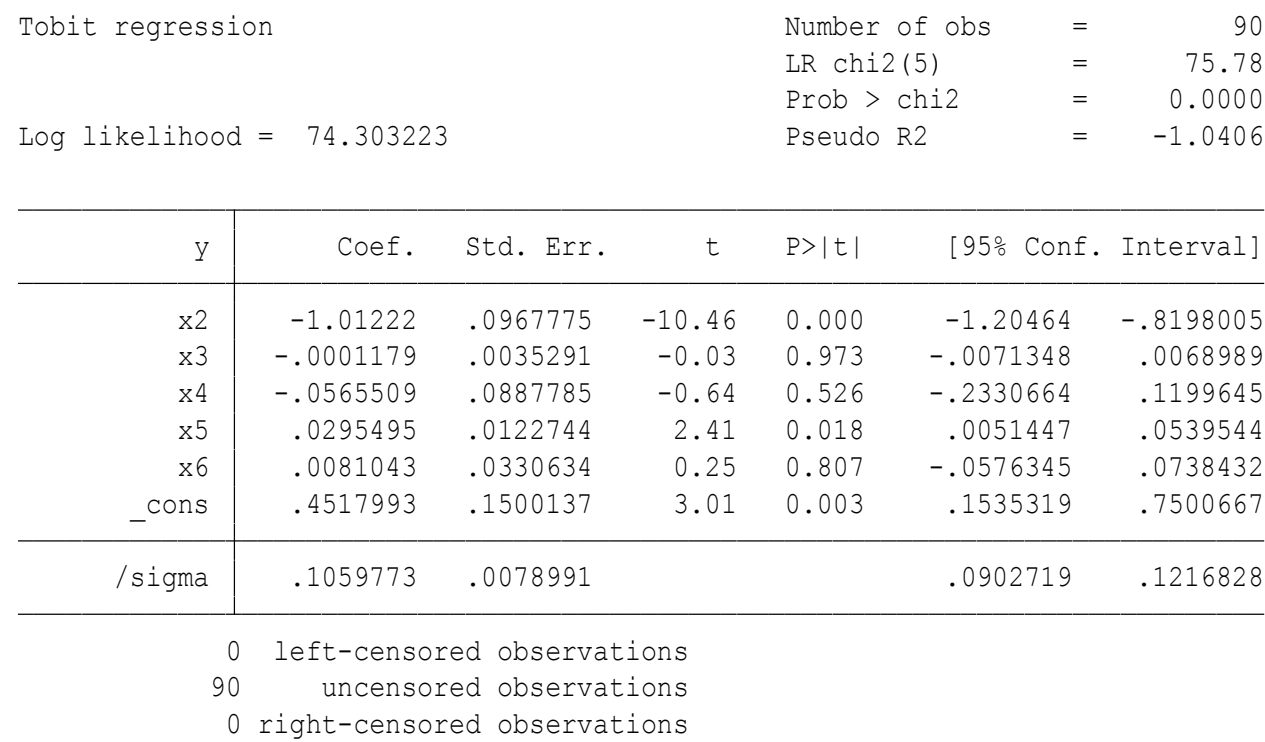

Table 5: OLS regression results

\begin{tabular}{|c|c|c|c|c|c|c|}
\hline Source & SS & $d f$ & MS & \multicolumn{2}{|c|}{ Number of obs $=$} & \multirow{2}{*}{$\begin{array}{r}90 \\
22.19 \\
0.0000\end{array}$} \\
\hline Model & 1.33529112 & 5 & .267058224 & $\operatorname{Pr}$ & F & \\
\hline Residual & 1.01080786 & 84 & .012033427 & & ared & 0.5692 \\
\hline Total & 2.34609898 & 89 & .026360663 & Ro & MSE & .1097 \\
\hline y & Coef. & Std. Err. & t & $P>|t|$ & [95\% Conf & Interval] \\
\hline$x 2$ & -1.01222 & .1001743 & -10.10 & 0.000 & -1.211428 & -.8130126 \\
\hline$\times 3$ & -.0001179 & .003653 & -0.03 & 0.974 & -.0073823 & .0071464 \\
\hline$x 4$ & -.0565509 & .0918945 & -0.62 & 0.540 & -.2392933 & .1261914 \\
\hline$x 5$ & .0295495 & .0127052 & 2.33 & 0.022 & .0042838 & .0548153 \\
\hline$\times 6$ & .0081043 & .0342239 & 0.24 & 0.813 & -.0599536 & .0761622 \\
\hline cons & .4517993 & .155279 & 2.91 & 0.005 & .1430099 & .7605886 \\
\hline
\end{tabular}


According to Circular 155/2015, the General Director is the manager of the bank's daily business, under the supervision of the Board of Directors and the Supervisory Board, responsible to the Board and the law for the exercise of rights and duties in accordance with the provisions of this Decree, other provisions of law and the Charter of the bank. In particular, the board of directors' activities include mechanisms: selection of executive board; implement guidelines and policies approved by the Board and supervise the business performance of the bank; explanation of the Executive Board with the Board and the owner. Accordingly, the Board is responsible for selecting and appointing the General Director, members of the Management Board and other senior management personnel of the bank. Moreover, the weak independence of the board in both banks is due to the dominance of controlling shareholders or a group of shareholders and related people. Therefore, the Chairman of the Board of Directors in the bank has supreme power and means the independence, control and management functions of the board of directors will be limited.

At the same time, with the optimal power from the Board of Directors, they hold the role of orientation, guidance, requirements, assignments ... to ensure the long-term objectives of the unit from a personal point of view. If the manager is too much dominated by maximizing profitability in a timely manner, there is no certain knowledge about CSR implementation, desire to implement CSR, meet financial information transparency and non-profit to stakeholders, has not yet turned CSR as a long-term competitive tool, approaching according to the direction of presenting international financial statements, .... And this is also the reason that the variables from X3 to X6 have no interaction to implement CSR of Vietnamese commercial banks.

\section{THE SOLUTION TO IMPROVE THE LEVEL DISCLOSURE OF SOCIAL RESPONSIBILITY INFORMATION VIETNAM COMMERCIAL BANKS}

\subsection{Discussion on causes impacts on the disclosure of CSR on the financial statements of Vietnamese commercial banks}

In our opinion, the status of CSR disclosure is quite limited in Vietnam due to the following barriers and challenges:

First of all, it is the understanding of enterprises in general and commercial banks in particular about inadequate CSR. Currently, public opinion is tending to associate charitable activities with corporate social responsibility, leading many businesses to understand only that CSR activities are charity. Meanwhile, charity is only a small part of CSR, but CSR is just a part of the overall criterion that constitutes corporate culture and business culture. Therefore, enterprises do not understand that the implementation of CSR is to show directly in all production and business activities of enterprises.

Secondly, an adverse impact on the implementation of CSR is that many commercial banks currently lack financial and technical resources to implement CSR standards.

Finally, even if the legal regulations were sufficient, the validity was too low. The legality of assessing the implementation of CSR in Vietnam is still limited. In fact, although specified under the rules of COC and other regulatory standards, such as SA8000, WRAP, ISO 14000, GRI ..., these standards are not agreements between the government or regulations of international conventions, thus lacking national legislation and the lack of international practice. Since then, if violations occur, whether inadvertently or intentionally unfortunate, leading to complaints against each other, it is very difficult to adjudicate.

\subsection{Recommending the notice of solution to promote CSR disclosure on the financial statements of Vietnamese commercial banks}

\section{Implications to the CSR literature:}

In connection with the results known above, this study makes a number of possible implications to the CSR literature. First, this study has opened an insight into CSR reporting practice of developing country's 
banking sector and thus expanding on previous literature that has focused mainly on developed countries. It has opened up further research avenues to compare and contrast these results with the banking sectors of other developing or developed countries. Second, it has broadened previous CSR research to the banking industry, which has not generally considered from sample companies because of the more rigorous regulatory rule. Third, from the study's finding, it is well documented that tendency of CSR items reporting in an isolated manner (lacking the adoption of any guidelines or implementing international practice) alone is not sufficient to attain overall superior level of disclosure unless, banks have the preparation to put GRI guidelines into practice or other forms of social reporting in future. Fourth, it underlines the importance of non-executive directors and existence of foreign nationalities to improve banks' communication on CSR information. And lastly, as an endeavour of revealing the CSR reporting intensity prevailing in different banks practices in Vietnam and hypothesising the impact of corporate governance elements on CSR, the findings will be a good beginning for further references or widening future study in the subject matter.

\section{Practical implications:}

- For Vietnamese commercial banks:

Convert awareness of CSR in the BOD: The role of the Board in the system of Vietnamese commercial banks needs certain moves to show the transformation and improvement of awareness and action point of view for CSR. Therefore, the solutions to improve governance capacity include raising awareness about CSR from management level to bank officials, building and completing CSR standards, improving financial management capacity, risk management and human resource management are aimed at creating a momentum for social responsibility development at commercial banks.

Determine specific sustainable development objectives in the operation strategy of Vietnamese commercial banks: One of the new points in Circular 155/2015/TT-BTC on information disclosure in the securities market is that public enterprises must disclose information related to sustainable development. This Circular officially takes effect from January 1, 2016. This means, presenting information about CSR has been an inevitable trend of businesses. Therefore, the term Sustainable Development Report is no stranger and is used to measure, publish and be responsible to stakeholders about the activities of enterprises towards sustainable development. The Sustainable Development Report not only facilitates businesses to consolidate cooperation with stakeholders, investors, and communities but also helps businesses manage business risks more effectively. Therefore, each bank needs to formally establish a set of social and environmental management policies and procedures for its own activities. At the same time, specifying specialized human resources, combining with the departments in the organization, recording the necessary data related to this issue, then assessing and analyzing the impacts and proposing the solutions (in conjunction with the consulting parties if necessary), determine targets, to gradually improve the negative impacts and assess the progress of these indicators each year; develop investment policies as well as the unit's social responsibility plans in the short and long term; expand financial products associated with CSR activities; promoting activities and information disclosure on CSR on the mass media and associated with the Bank's business activities.

Responding to the compliance aspect in the organizational structure of commercial banks: Since the membership of the Board of Directors is in fact less than the norm, the opinions of these members will not be passed, if the remaining members are not in the same opinion. Therefore, the listed company needs to ensure that the number of independent members of the Board of Directors must account for over $50 \%$, but at least there must be executive members.

Ensure the principle of honesty and understandable when presenting CSR information on financial statements: CSR disclosure is a form of non-financial information, which is mainly the Executive Board's intentions and interpretations of the company's perspective. These are information that have no standards to measure. So the truthfulness of the information is at the base of forming information. Therefore, the mechanism to best monitor this information is primarily from within, but the independent members of the BOD play an essential role. Another aspect of honest information is that businesses need to disclose and 
explain the reasons for choosing policies and accounting estimates. This information helps financial statements users to rely on estimates that are consistent with the characteristics of their operations.

- $\quad$ For the State and management agencies:

Changing the perception of CSR of stakeholders is what determines the success of the implementation process in practice. Thus, the Government, the State Bank, the Ministry of Finance, ... should soon issue legal documents to clarify the orientation, management mechanism, methods of publication, criteria to assess enterprises when receiving beneficial projects, .... This is the fundamental cause that can form a habit instead of being in a state of encouragement because it has not yet connected the clear relationship between cost and benefits for organizations when implementing CSR.

Concretizing the set of CSR evaluation indicators at commercial banks, it should soon be issued and piloted in some of the top commercial banks in Vietnam. Notably, this set of evaluation indicators should be built on the basis of referring to the set of indicators mentioned in the GRI G4 guidelines and adjusted to conform to the ISO 26000 standards and specific characteristics of banking industry.

The State Bank should closely coordinate with other agencies such as the Ministry of Planning and Investment, the Ministry of Finance, and the Ministry of Natural Resources and Environment in advising and advising the Prime Minister and implementing activities aimed at realizing currently inspecting and supervising and making regular assessment reports to have timely solutions; coordinate and support propaganda and awareness raising on CSR implementation in Vietnamese commercial banks.

Promulgating policies to encourage and support enterprises to implement social responsibilities such as "green" brand awards, granting certificates to businesses to ensure requirements related to CSR standards in COC is applied ... At the same time, measures need to be strong enough to handle violations of enterprises that do not complete CSR during operation. In addition, strengthen cooperation with developed countries to receive advice to support CSR implementation in Vietnam.

\section{CONCLUSION}

At UN discussions, countries in the Organization for Economic Cooperation and Development (OECD) and the G20 have shown a high international consensus that: to enhance financial stability and long-term economic development requires rapid improvement of E\&S (Environmental and Social Governance) activities in businesses. One of the activities that the UN aims to encourage businesses to implement the Sustainable Development Report. Sustainability of listed organizations on the stock market, almost always refers to the adoption and implementation of environmental obligations, comprehensive social policies and governance structures aimed at reduce risks and volatility, while helping to strengthen the long-term beneficial effects on production and business activities. In recent years, many pioneering corporations have responsibility for investors, Government and society have begun to focus on issues to ensure sustainability in business operations, supply chain and your investment decisions.

After 30 years of renovation, Vietnam's commercial banking system has changed, developed and fluctuated in association with the evolution of the economy. In particular, after implementing the Scheme on restructuring credit institutions system in the period of 2012 - 2016, the result was improved financial status of banks, order, discipline and marketing principles in banking operations has been reset. However, in order for the banking system to operate sustainably and effectively in the context of increasing economic integration when participating in the ASEAN Economic Community (AEC) and the New Generation Free Trade Agreement, The banking system not only improves the capacity of capital raising and administration, but also the credit rating of banks needs to be concerned. Therefore, it is necessary to have more research projects to assess and rank Vietnamese commercial banks based on financial indicators in the period of restructuring the system of credit institutions in this period according to the sustainable development trend through the integration of CSR information into financial statements. 


\section{REFERENCES}

[1] Bernad, Cristina \& Fuentelsaz, Lucio \& Gómez, Jaime, The effect of mergers and acquisitions on productivity: An empirical application to Spanish banking, Omega, Elsevier, vol. 38, no. 5, pp. 283-293, 2010.

[2] Carroll A.B, Corporate Social Responsibility, Business and Society, vol. 38, no. 3, pp. 268-295, 1999.

[3] Gray R., Kouhy R. and Lavers S., Constructing a research database of social and environmental reporting by UK companies, Accounting, Auditing and Accountability Journal, vol. 8, no. 2, pp. 78-101, 1995.

[4] Gray R., Kouhy R. and Lavers S., Corporate social and environmental reporting: a review of the literature and a longitudinal study of UK disclosure, Accounting, Auditing and Accountability Journal, vol. 8, no. 2, pp. 47$77,1995$.

[5] Gray R., The social accounting project and accounting, organisations and society: privileging engagement, imaginings, new accountings and pragmatism over critique?, Accounting, Organisations and Society, vol. 27, no. 7, pp. 687-708, 2002.

[6] GRI.G4, Reporting Principles and Standard Disclosures

[7] Habib Zaman Khan, The effect of corporate governance elements on corporate social responsibility (CSR) reporting: Empirical evidence from private commercial banks of Bangladesh, International Journal of Law and Management, vol. 52, no. 2, pp. 82-109, 2010.

[8] IFC Advisory Program in East Asia - Pacific, Guidelines for reporting sustainable development

[9] Jo H. and Harjoto M., Corporate Governance and Firm Value: The Impact of Corporate Social Responsibility, Journal of Business Ethics, vol.103, no.3, pp.351-383, 2011.

[10] Khondkar Karim, Eunju Lee and Sanghyun Suh, Corporate social responsibility and CEO compensation structure, Advances in Accounting, vol.40, pp.27-41, 2018.

[11] Milton Friedman, The Social Responsibility of Business is to Increase its Profits, Corporate Ethics and Corporate Governance, Springer, pp.173-178, 1970.

[12] Ministry of Finance, Circular No. 155/2015 / TT-BTC guiding information disclosure on the stock market, 2015.

[13] Nguyen Thi Mai Huong, Nguyen Thi Phuong Thuy, The presentation of Corporate Social Responsibility Awareness and application in Vietnam, Proceedings of International Conference on Accounting and Finance 2016 (ICOAF 2016)

[14] Nguyen Thi Mai Huong, Prospects for implementation of integrated financial statements of listed companies, National workshop at Quy Nhon University, 2017.

[15] Organization for Economic Cooperation and Development, OECD's Guide to Corporate Governance in StateOwned Enterprises

[16] Paul M. Healy and Krishna G. Palepu, Information asymmetry, corporate disclosure, and the capital markets: A review of the empirical disclosure literature, Journal of Accounting and Economics, vol. 31, no. 1-3, pp. 405440, 2001.

[17] Porter M.E., Kramer M.R., Creating Shared Value, Managing Sustainable Business, Springer, pp. 323-346, 2019

[18] R Edward Freeman, Stakeholder management: framework and philosophy, Pitman, 1984 


\section{COMMERCIAL BANKS}

[19] VCCI, Sustainable Business Index, 2016

[20] Vietnam Commercial Bank, Annual Report for the period 2014-2016.

[21] Zeeshan Hamid, Sarwar Mehmood Azhar, Hammad Basir, Strategic Corporate Social Responsibility: Literature Review and Value Chain Activities Filter, International Journal of Social, Management, Economics and Business Engineering, vol.8, no.10, pp.3165-3177, 2014.

Received on February 1st, 2019

Accepted on March 25th, 2019 